\title{
EVALUATION OF THE ENVIRONMENTAL IMPACT OF AN IRRIGATION NETWORK IN A RAMSAR AREA OF THE GREEK PART OF THE STRYMONAS RIVER BASIN USING A COUPLED MIKE SHE/MIKE 11 MODELLING SYSTEM
}

\author{
CHALKIDIS I.,** \\ SEFERLIS M. ${ }^{2}$ \\ SAKELLARIOU-MAKRANTONAKI M. ${ }^{1}$
}

\author{
University of Thessaly, School of Agricultural Sciences \\ Dept. of Agriculture, Crop Production and Agricultural Environment \\ Agricultural Hydraulics Laboratory \\ Fytoko Street, Volos, 38446, Greece \\ The Goulandris Natural History Museum \\ Greek biotopes/wetlands centre (EKBY) \\ $14^{\text {th }} \mathrm{Km}$ Thessaloniki - Mihaniona \\ P.O. BOX 60394, 57001 Thermi, Greece
}

Received: 22/05/2014

Accepted: 11/01/2016

Available online: 15/01/2016 *to whom all correspondence should be addressed: e-mail: ichalkidis@uth.gr

\section{ABSTRACT}

The need for efficient and economical use of the world's water requires the implementation of modern methods to make decisions about water management. This inspired the principal philosophy of the management study of the Hellenic part of the Strymonas River catchment $\left(6400 \mathrm{~km}^{2}\right)$. An important issue in such studies is to simulate the hydrology of the river catchment. The state-of-the-art couple model MIKE SHE/MIKE 11 is a powerful, physically-based distributed hydrological and hydraulic simulation tool. To determine water balance, hydrology and hydraulic functions in the river catchment a water level monitoring network was established. Data collection was performed during 2004 and 2006. The philosophy and main assumptions that underlie the current work are described. Furthermore, the effectiveness of the irrigation networks in the Strymonas River basin is checked. Finally, the negative effect of the current irrigation network on the lake's water level fluctuation is pointed out and simple but effective solutions are proposed.

Keywords: Kerkini, Strymon, hydrology, modeling, irrigation, environment.

\section{Introduction}

The threats of climate change and future water shortage drive the search for integrated and sensible management of valuable water resources. A powerful tool for water resources management is a simulation model of hydrological catchments such as MIKE SHE/MIKE 11. MIKE SHE/MIKE 11 has been employed to simulate hydrological catchments in numerous cases. Refsgaard (1997) in the Danish Karup catchment $\left(440 \mathrm{~km}^{2}\right.$ with $500 \times 500 \mathrm{~m}^{2}$ grid) demonstrated the steps and the inherent assumptions in distributed modelling. Singh et al., (1999) used MIKE SHE to simulate the hydrological balance of a 6.94 $\mathrm{km}^{2}$ watershed in order to improve the irrigation plan. Feyen et al., (2000) applied MIKE SHE in the 600 $\mathrm{km}^{2}$ catchment of Grote and Kleine Gete in Belgium.

Adersen et al., (2001) presented the construction and validation of a distributed hydrological modelling of the Senegal River catchment $\left(375,000 \mathrm{~km}^{2}\right)$. Thompson et al., (2004) applied the coupled MIKE-

Chalkidis I., Seferlis M. and Sakellariou-Makrantonaki M. (2016), evaluation of the environmental impact of an irrigation network in a Ramsar area of the Greek part of the Strymonas river basin using a coupled MIKE SHE/MIKE 11 modelling system, Global NEST Journal, 18(1), 56-66. 
SHE/MIKE 11 modelling system to lowland wet grasslands $\left(8.7 \mathrm{~km}^{2}\right)$ in southern England. Sahoo et al., (2006) investigated flash flood events in a small catchment of $25 \mathrm{~km}^{2}$ in Hawaii, USA, using MIKE SHE/MIKE 11.

Above references show that $200 \times 200$ net is the proper one for the specific surface under research.

Within the frame of a project called "LIFE - Strymon" the hydrological modelling system MIKE SHE / MIKE 11 was used to model the Hellenic section of the Strymonas River catchment. MIKE SHE/MIKE 11 enable testing of future scenarios of water management and may assist in the selection of the most applicable ones. Decision making for future actions to sustainable water management is armed with best practical results. In addition, EU's demand, as expressed in the Water Framework Directive, is the use of sophisticated simulation models for management.

Low efficiency in the irrigation networks in the sensitive Strymonas River catchment of North Greece has a strong environmental impact, which is the main subject of research of the "LIFE-Strymon" project. The main issues in Strymonas River catchment are the following:

a) Loss of water due to the incomplete or damaged irrigation network,

b) Undesirable alteration of the water level fluctuation affecting ecosystem of Kerkini Lake,

c) Intrusion of seawater into the river estuary during the irrigation period due to low discharge rate.

\section{Material and Methods}

\subsection{Hydrological model}

In order to simulate interactions between surface water bodies, the saturated and unsaturated zone as well as the conjunctive use of surface water and groundwater in the Strymonas basin, an integrated hydrological modelling system MIKE SHE/MIKE 11 has been employed.

MIKE SHE is a fully distributed, physically-based, finite difference hydrological modelling system coupled dynamically with MIKE 11 that contains an implicit, finite difference computation of unsteady flows in rivers and estuaries. The following major water flow processes were simulated simultaneously in the basin: runoff from the surrounding sub-basins, overland sheet flow and depression storage, infiltration and storage in the unsaturated zone, dynamic exchange between unsaturated zone and groundwater (recharge), dynamic exchange between aquifers and river (seepage), groundwater flow, storage and potential heads, river/canal flow and water levels, evapotranspiration losses, drainage effects, and effects arising from the allocation of water for irrigation. MIKE SHE/MIKE 11 consists of several components (modules) that simulate all the above processes.

In the mountainous areas of the basin where human activity is scarce, a lumped hydrological model was used. Specifically, the NAM model, a deterministic, lumped and conceptual Rainfall-runoff model (DHI 2003b) which constitutes a module of MIKE 11, was applied for the estimation of the surface runoff and ground water recharge. All subcatchments were delineated using GIS in order for NAM to be applied individually to each one of them.

\subsection{Study area}

The Greek part of Strymonas River basin is located at the north of Central Macedonia Region in the $11^{\text {th }}$ Water District of Greece (Fig.1), and covers $6400 \mathrm{~km}^{2}$. Strymonas River and Lake Kerkini are the largest surface water bodies in the basin that support natural groundwater recharge in the basin. Lake Kerkini is an artificial lake fed by Strymonas constructed during 1933-36 mainly for flood protection caused by Strymonas River. It was subsequently used as reservoir for irrigation water. Since its construction, a unique wetland ecosystem has been developed, which is protected under Greek and EU legislation and which is one of Europe's most important Ramsar sites. Strymonas River outflows to the Strymonikos gulf, a coastal ecosystem which is very important for fisheries, biodiversity and tourism. 


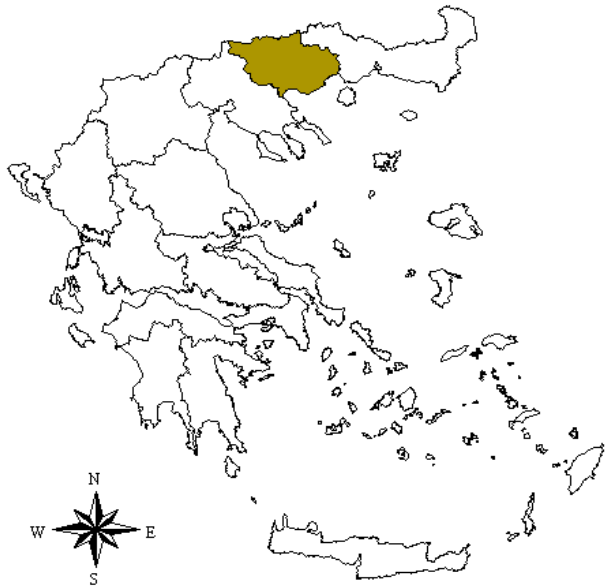

Figure 1. Strymonas River basin in the 11th of 14 Greek water districts

Agriculture imposes challenges to water resources management in the basin and it occurs in the lowland (elevation $>100 \mathrm{~m}$ ). Agricultural land covers about 100,000 ha. This area is irrigated and drained through a dense network of canals and ditches.

The Strymonas River flows directly into Lake Kerkini from autumn to spring after it enters Greece from Bulgaria. Downstream of the lake, Strymonas River crosses its floodplain for $77 \mathrm{~km}$ and outflows into Strymonikos gulf. This gulf is the final receiver of all the surface runoff of the basin. The surrounding mountainous area of the floodplain (areas with elevation $>100 \mathrm{~m}$ ) drains through a number of streams, either into Lake Kerkini or into Strymonas River. The western mountainous area downstream lake Kerkini, drains through several streams that outflow directly into Strymonas River. In the east, the Belitsa drainage ditch receives most of surface runoff from the floodplain and mountainous areas which finally outflows into Strymonas River. The rest of the eastern mountainous area drains directly to Strymonas River through the Agios loannis stream and other small drainage ditches. The north and west mountainous area drains through a number of streams directly into either the Strymonas River or Lake Kerkini.

During summer months, about $11 \mathrm{~km}$ after Strymonas enters Greek territory, part of its discharge diverts through the sluicegates $Y 1$ into three irrigation networks, while the remaining discharge outflows into Lake Kerkini (Fig. 2). Three more irrigation networks receive water directly from the lake through the flow control structures $\mathrm{Y} 2$ and $\mathrm{Y} 3$ (Fig. 2). Meanwhile, Belitsa receives drainage from all upstream irrigation networks (almost all the networks located at the east of Strymonas River) and supplies with water three other irrigation networks (Fig. 2). The excess water of Belitsa ditch outflows again into Strymonas River which in turn is consumed into the rest irrigation networks.

The cultivated area in the Greek part of Strymonas river Basin is one of the richest areas in Greece in surface water availability. Many soil studies in the floodplain have shown that crops could meet their irrigation needs directly from the capillary zone. The lake embankments, the dam modification and the constant improvements/modifications to the irrigation network by the Directorate of Land Reclamation since 1984 have reduced the use of groundwater resources. Combined with recent hydraulic works on Lake Kerkini and the supporting land reclamation works, the consumption of ground water was reduced to a small percentage compared to the consumption of surface water use in Strymonas basin. For this reason, data related to the ground water are limited. Where infrastructure from surface water irrigation does not exist, the irrigation needs covered by ground waters. Nowadays, a $5 \mathrm{MW}$ Hydroelectric station operates at lake Kerkini's dam. This Hydroelectric station was constructed after the results and recommendations of this study. The effect of the hydroelectric station does not lead to water management changes and the way it works is compatible with the ecological functioning of the lake (high and stable water level without major fluctuations). 

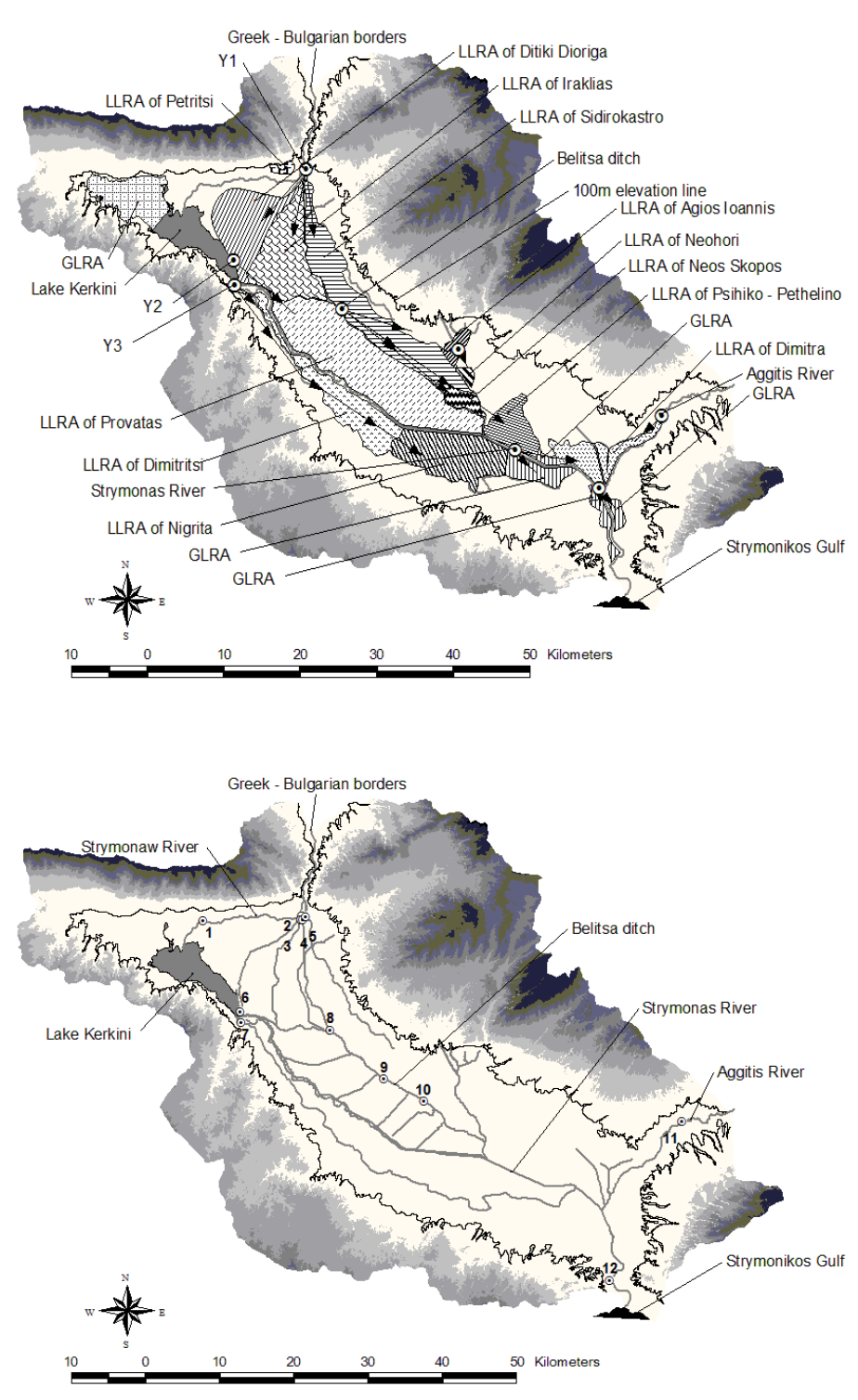

Figure 2. Water source for the irrigation networks in Strymonas basin

\subsection{Hydrological regime monitoring network}

In order to cross-check the hydrological model, a network of gauges was established in the catchment to record surface water level.

The surface water level monitoring network includes 12 water level auto-recorders (Fig. 3). The main objective is to provide an adequate number of water depth time-series for the calibration and validation of the hydraulic model of the catchment.

Additionally, the monitoring network includes discharge measurements at the same locations where the water level auto-recorders have been set so that water level-discharge curves can be produced.

The instruments were placed at the inlets and outlets of natural water bodies and the irrigation and drainage networks were placed in the catchment.

\subsection{Model set up}

In the floodplain (elevation $<100 \mathrm{~m}$ ) of Strymonas basin full MIKE SHE / MIKE 11 modelling was applied (Halkidis et al., 2004; Halkidis and Papadimos 2007a; DHI 2003a). The model area was partitioned into a 
number of computational cells to enable the numerical solution of the governing equations. The spatial scale of MIKE SHE (grid size) was chosen either to address regional basin issues or to conduct detailed studies of certain areas.

The principal information necessary for the simulation tool (MIKE SHE) is the digital elevation model (DEM).

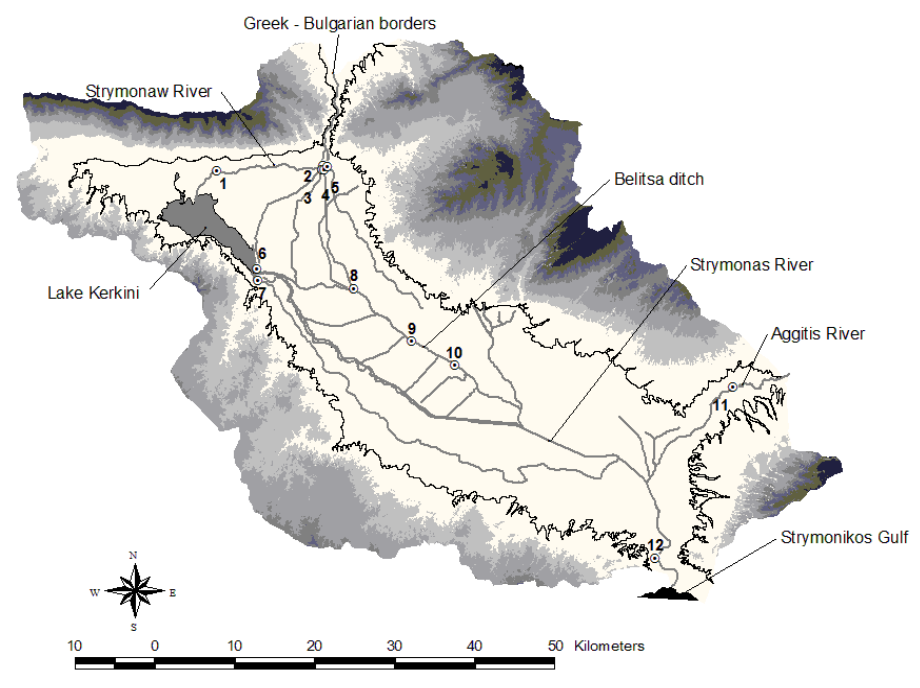

Figure 3. Surface water level monitoring network in Strymonas River basin

The area below the $100 \mathrm{~m}$ contour was selected as the main study area (domain area of $1510 \mathrm{~km}^{2}$ ) and this is where agriculture is actually practiced. This area is partitioned into cells of $400 \times 400 \mathrm{~m}^{2}=16 \mathrm{ha}$. The hydrological simulation of area above the $100 \mathrm{~m}$ contour is regarded as indirect discharge of the streams of the catchment.

The distribution of rainfall was calculated with data from 11 rain gauges in the catchment using Thiessen polygons. Rainfall records are introduced into the model as a daily time-series. The next step was to map the existing irrigation network on 1:20000 scale and the water sources of each network (Fig. 2). Land uses and crop distribution in each cell were derived from satellite images for each simulated year (2004-2006). Additionally, crop factors such as time-varying values of Leaf Area Index (LAI) and Root Depth (RD) were derived. The reference evapotranspiration was obtained from the Directory of Land Reclamation and has been tested many times.

The next step was to input hydraulic simulation data from the hydrological networks. This required the coupling of MIKE SHE to MIKE 11 to calculate the movement of water in Strymonas River canals and ditches of the river catchment (Halkidis et al., 2004; Halkidis and Papadimos 2007a).

Data loaded to MIKE 11 included:

1. Information about the irrigation network, such as hydraulic elements for controlling and managing water discharge. This enables a simulation of existing water management which determines water discharge at abstraction points and irrigation ditches.

2. Cross-section details for each branch of the irrigation network.

3. Marginal conditions of the outer branches regarding their discharge or water level.

4. Data for calculating hydrology of the area above the $100 \mathrm{~m}$ contour where the NAM (NAM is a lumped, conceptual rainfall-runoff code for hydrological simulation) was applied.

5. Many other specific hydraulic parameters necessary for the NAM.

Data for MIKE SHE referring to surface runoff include:

- the Manning factor $(M=1 / n)$ was regarded uniform for the area $M=10 \mathrm{~m}^{1 / 3} \mathrm{~s}^{-1}$ 
- the water surface height before runoff commences. This was considered 0 for the whole study area. However, the results of a 1-month simulation were loaded as initial water depth on the surface of the river catchment. This does not include the lake, where daily water level records were available.

A uniform soil type of silt loam was selected since this or a similar type predominates. For the calculation of the water movement in the unsaturated zone, the Van Genuchten function (Van Genuchten, 1980; Antonopoulos, 1999; DHI 2003) was used. Factors of the Van Genuchten function were adopted from the literature (Antonopoulos, 1999).

Finally, drainage data for the area were loaded. Drainage starts when the water table rises above the level of the drains and it is proportional to the difference in level between the water table and the drainage depth. The drainage depth of $1.5 \mathrm{~m}$ was estimated by Land Reclamation Agency (LRA) of Serres (personal contact) as the most appropriate for the drain area.

Furthermore, the drainage time constant or drainage coefficient was unknown and was estimated. This factor determines the velocity of the drainage and influences mainly the peak of the hydrograph (Feyen et al., 2000).

The crop pattern in a floodplain affects the pressure on the environment in terms of irrigation water demand and nutrient loadings. Remote sensing is a relatively cheap and effective way to determine crop patterns. In the frame of the Strymonas LIFE project, satellite images were used to investigate crop patterns and effective water management.

Satellite images from SPOT 5, 10x10 m resolution were taken from April to August in 2004, 2005 and 2006. Images were registered to Greek Geodetic Reference System '87 on ERDAS IMAGINE 8.4. Different thematic maps (1:50.000) were used, a Digital Elevation Module (DEM) of the basin was constructed and a geo database of CORINE Landcover. About 150 spectrum signatures of each crop were identified in the field. Precise coordinates of each spot were recorded on portable GPS and ArcPad system (Apostolakis, 2007). Crop pattern analysis includes identification of dwelling areas, clouds, rice fields, etc.

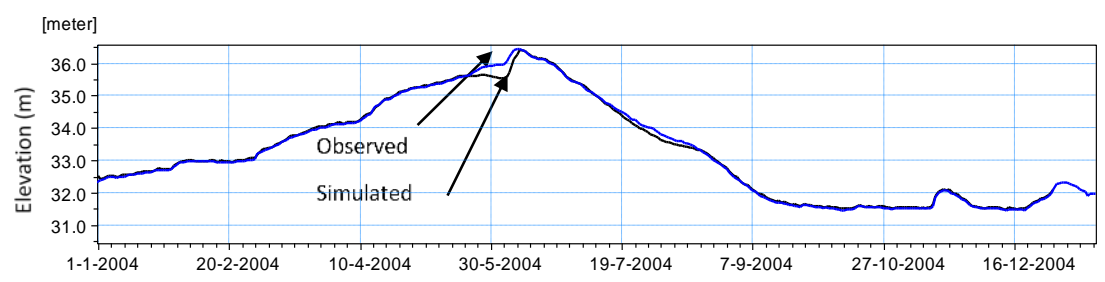

Figure 4. Simulated and observed water level time series of Lake Kerkini for the year 2004

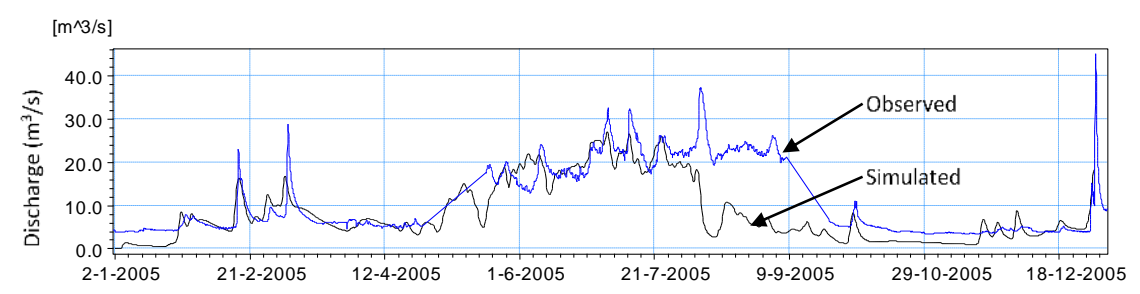

Figure 5. Simulated and observed discharge time series in Belitsa ditch for the year 2005

The results of the crop spatial distribution for each year were organized in three ways:

1. A map of crop spatial distribution

2. A table of crop types, their area and an assessment of reliability of identification

3. GIS files of spatial coordinates of each crop. 
The agreement of simulations with observed data achieved by the calibration and validation of the MIKE SHE / MIKE 11 model of the catchment. This agreement is graphically shown and some of the graphs are given in Figures 4-6.

The difference between observed and calculated discharge values in Belitsa ditch after 31 July (Fig 5) is due to an expected interruption of rice fields irrigation which was simulated in the model. In fact, however, water supply to irrigation networks in the rice fields was not interrupted.

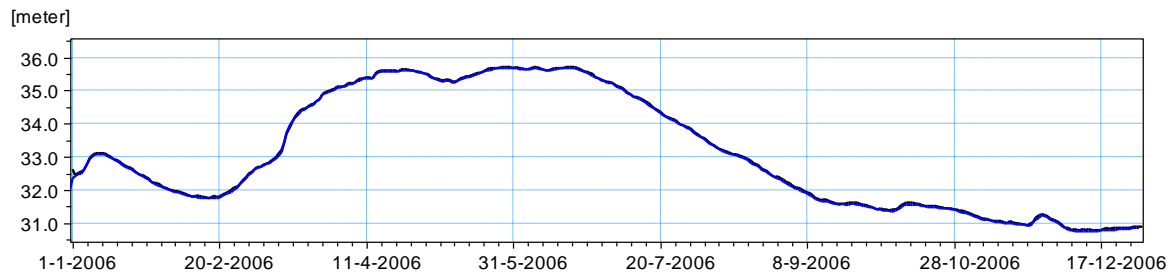

Figure 6. Simulated and observed water level time series of Lake Kerkini for the year 2006

It is necessary to mention here that efficient coefficient \% is the percentage of the inflow that is used for irrigation.

Response of the model to real irrigation needs is immediate as shown in Fig. 5, which means that important water savings could be achieved.

After the 1st of August extra amounts of water are available to cultivators, because the water managers should reduce the level of the lake to regulate safely inflows from autumn precipitation as it is presented in Figure 5. The model works properly for the irrigation needs

\section{Results and discussion}

Satisfactory calibration of the model (Halkidis and Papadimos, 2007b) lets us draw valuable conclusions on the pressure exerted on water resources and ecosystems of the basin by irrigation and general water management.

Table 1. Annual water volume and demand in irrigation networks fed by Strymonas River and Lake Kerkini and respective efficiency coefficient.

\begin{tabular}{|c|c|c|c|c|c|c|c|c|}
\hline & \multirow[t]{2}{*}{ Water volume } & \multicolumn{3}{|c|}{$\begin{array}{l}\text { Irrigation networks fed directly } \\
\text { from Strymonas River }\end{array}$} & \multicolumn{3}{|c|}{ Irrigated areas fed from Lake Kerkini } & \multirow[b]{2}{*}{ Total } \\
\hline & & Ditiki & Iraklia & Sidirokastro & $\begin{array}{c}\text { Dimitritsi, } \\
\text { Nigrita, GLRA* }\end{array}$ & Provatas & Sub-total & \\
\hline \multirow{3}{*}{ ঠ্ণ } & Inflow $\left(10^{6} \mathrm{~m}^{3}\right)$ & 25.69 & 43.92 & 47.46 & 136.74 & 289.95 & 426.7 & 543.76 \\
\hline & $\begin{array}{l}\text { Irrigation needs } \\
\qquad\left(10^{6} \mathrm{~m}^{3}\right)\end{array}$ & 7.27 & 24.52 & 28.12 & 67.04 & 156.43 & 223.5 & 283.38 \\
\hline & Efficient coef. (\%) & 28.2 & 55.8 & 59.4 & 49.00 & 54 & 52.4 & 52.11 \\
\hline \multirow{3}{*}{$\stackrel{n}{\circ}$} & Inflow $\left(10^{6} \mathrm{~m}^{3}\right)$ & 38.16 & 52.28 & 58.85 & 163.21 & 328.2 & 491.4 & 640.7 \\
\hline & $\begin{array}{l}\text { Irrigation needs }\left(10^{6}\right. \\
\left.\mathrm{m}^{3}\right) \\
\end{array}$ & 7.77 & 24.9 & 31.18 & 63.55 & 144.24 & 207.8 & 271.64 \\
\hline & Efficient coef. (\%) & 20.4 & 47.6 & 53.00 & 38.9 & 43.9 & 42.3 & 42.40 \\
\hline \multirow{3}{*}{ ஜ } & Inflow $\left(10^{6} \mathrm{~m}^{3}\right)$ & 38.32 & 46.22 & 48.93 & 122.34 & 300.85 & 423.2 & 556.66 \\
\hline & $\begin{array}{l}\text { Irrigation needs } \\
\left(10^{6} \mathrm{~m}^{3}\right)\end{array}$ & 8.42 & 25.34 & 26.17 & 52.31 & 151.78 & 204.1 & 264.02 \\
\hline & Efficient coef. (\%) & 22.0 & 54.8 & 53.5 & 42.8 & 50.5 & 48.2 & 47.43 \\
\hline 0 & Efficient coef. (\%) & 22.96 & 52.49 & 55.06 & 43.31 & 49.23 & 47.4 & 47.04 \\
\hline
\end{tabular}

* irrigated areas fed from Lake Kerkini and under control of GLRA, Fig. 2.

The term "pressure" covers the amount of surface and ground irrigation water considered in both space and time. The mean annual volume flowing into the Greek part of the river basin from Bulgaria is about $2.65 \times 10^{9} \mathrm{~m}^{3}$. Table 1 shows water volumes in the irrigation networks (Fig.2), the water needs of crops 
(including losses due to irrigation practices) and the efficiency coefficient of each irrigation network which is fed directly from the river or lake.

The main threat to the ecological balance of Lake Kerkini is extensive water level fluctuation resulting from the applied water management. Gerakis et. al. (2007) suggested that $+35 \mathrm{~m}$ should be the maximum and $+32 \mathrm{~m}$ the minimum water level to sustain the ecology of the lake. Current legislation requires a maximum water level of $37 \mathrm{~m}$ above sea level for flood protection, while irrigation water storage requires a maximum depth of $35.70 \mathrm{~m}$ and a minimum of $31.70 \mathrm{~m}$.

The observed water level, the minimum and maximum environmental water level and the water volume variation of the Lake Kerkini is illustrated in Fig. 7. Cumulative water volume abstraction has been calculated using the water discharge at the head of irrigation networks that fed from the Lake Kerkini and it is shown in Fig. 7. From Fig. 7 and Table 1. Concluded: If water level in the lake does not rise above maximum environmental level of $35 \mathrm{~m}$ (water stored is $285 \times 10^{6} \mathrm{~m}^{3}$ ) at the beginning of the irrigation period and does not decrease due to irrigation below $+32 \mathrm{~m}$ (water stored is $71 \times 10^{6} \mathrm{~m}^{3}$ ) then net water volume for irrigation is $214 \times 10^{6} \mathrm{~m}^{3}$. Hence in $2004,9.5 \times 10^{6} \mathrm{~m}^{3}(223.5-214=9.5)$ was needed. $\ln 2005$, there were $6.2 \times 10^{6} \mathrm{~m}^{3}(207.8-214=-6.2)$ further from the needs and in 2006 , there were $6.2 \times 10^{6} \mathrm{~m}^{3}(204.1-214=-$ 9.9) further from the needs. Assuming that during irrigation period the inflow in the Lake Kerkini covers the water loses from the Lake, 2004 would be the only year that there was a need for extra irrigation water. But in reality the inflow in the lake Kerkini was extremely higher than the water losses. So from the data that shown at Fig. 7 , on June $9^{\text {th }}, 2004$, when maximum water level of the lake rose to $36.45 \mathrm{~m}$ sea level, then net water storage capacity reached $397 \times 10^{6} \mathrm{~m}^{3}$. Assuming lower ecological water level is maintained, then net irrigation water is $326 \times 10^{6} \mathrm{~m}^{3}$. Total irrigation water volume for the whole irrigation period in 2004 was calculated to $346 \times 10^{6} \mathrm{~m}^{3}$ as shown at the Cumulative water volume abstraction curve. While until the water level reach the peak, $111 \times 10^{6} \mathrm{~m}^{3}$ had already been distributed and $235 \times 10^{6} \mathrm{~m}^{3}$ more was applied. So if the water level peak in the Lake was steady at the ecological level of $+35 \mathrm{~m}$ then the stored water would be $285 \times 10^{6} \mathrm{~m}^{3}$. Therefore, the stored volume at the ecological level of $+35 \mathrm{~m}$ covers the irrigation needs even with the existing non-rational management. (Fig. 7 year 2004).

On June $13^{\text {th }} 2005$ when maximum water level was $36.45 \mathrm{~m}$ sea level, net water volume storage was $326 \times 10^{6} \mathrm{~m}^{3}$. The Total applied irrigation water for the whole irrigation period in 2005 was calculated to $470 \times 10^{6} \mathrm{~m}^{3}$. While during the water level peak, $165 \times 10^{6} \mathrm{~m}^{3}$ had already been distributed and $305 \times 10^{6} \mathrm{~m}^{3}$ more was applied (Fig. 7 year 2005).

Finally on June $21^{\text {st }}, 2006$, maximum water level was $35.67 \mathrm{~m}$, net water volume reached $264 \times 10^{6} \mathrm{~m}^{3}$. The Total applied irrigation water volume for the whole irrigation period in 2006 was calculated to $421 \times 10^{6}$ $\mathrm{m}^{3}$. While during the water level peak, $167 \times 10^{6} \mathrm{~m}^{3}$ had already been distributed and $421 \times 10^{6} \mathrm{~m}^{3}$ more was applied (Fig.7 year 2006).

\section{Conclusions}

The mean annual water volume drawn from Strymonas River and Lake Kerkini during 2004-2006 and channeled to irrigation networks was about $580 \times 10^{6} \mathrm{~m}^{3}$. This volume represents $22 \%$ of the mean annual discharge of the river where it enters Greece from Bulgaria (Fig. 5). The mean annual irrigation water volume needs during $2004-2006$ were about $273 \times 10^{6} \mathrm{~m}^{3}$, resulting to a downstream loss of almost $50 \%$ of the net irrigation water (Table 1). . Efficiency of irrigation networks does not exceed $43-55 \%$ (Table 1 ) and occasionally it is considerably lower (23\%) as in the case of Ditiki.

The low efficiency of the total irrigation system is attributed to the age of network, the absence ofconcrete-lined channels and inadequate water discharge control account.The current results suggest there is considerable potential to save water by improving the irrigation system, thereby limiting human pressure on water resources in the catchment, especially Kerkini's sensitive ecosystem.

Pressure on the ecosystem of Lake Kerkini exerted by the current irrigation regime is illustrated in Fig. 7. In the 3-year period of the study (2004 - 2006), water stored in the lake exceeded not only the desirable ecological level but also the level prescribed by Greek legislation for irrigation purposes. 


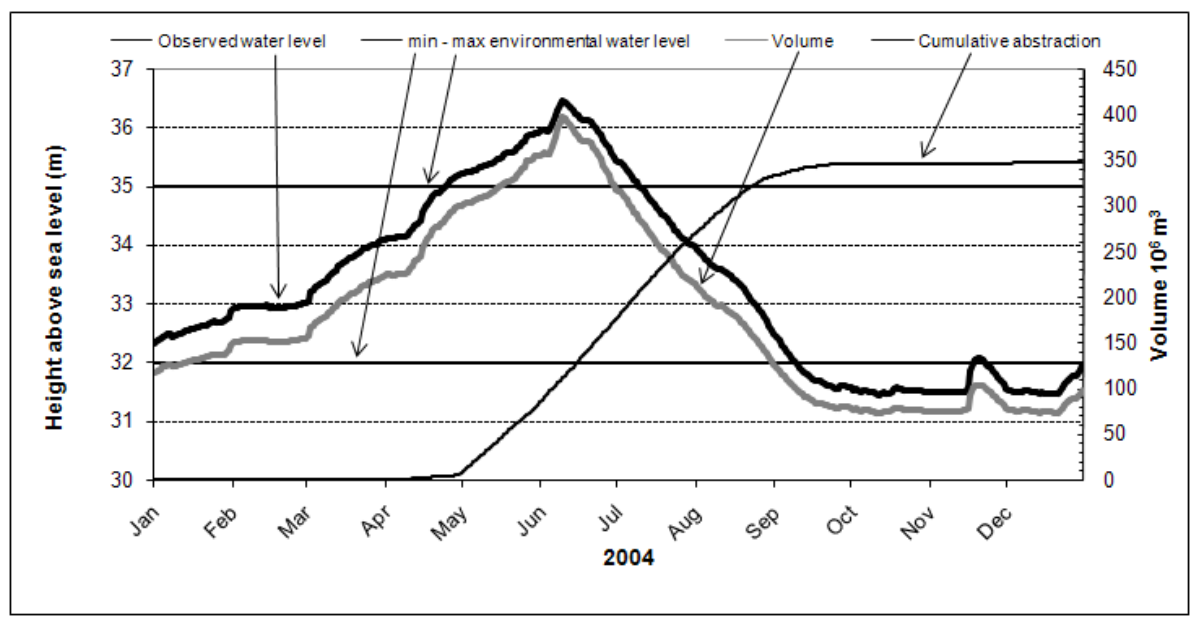

(a)

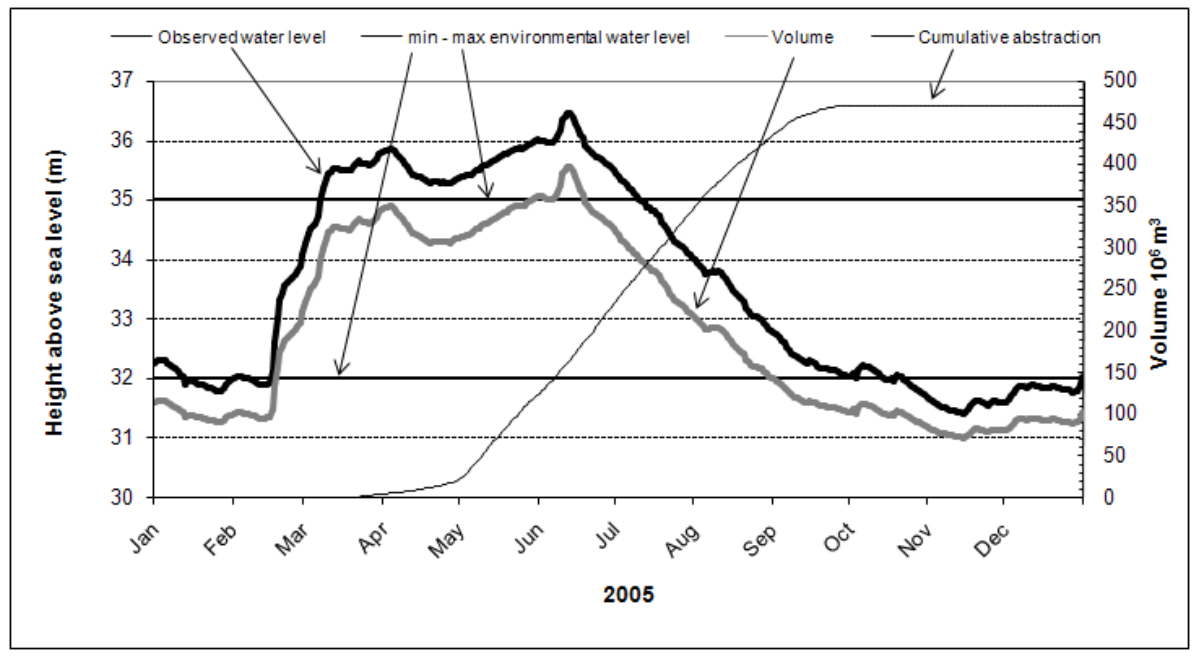

(b)

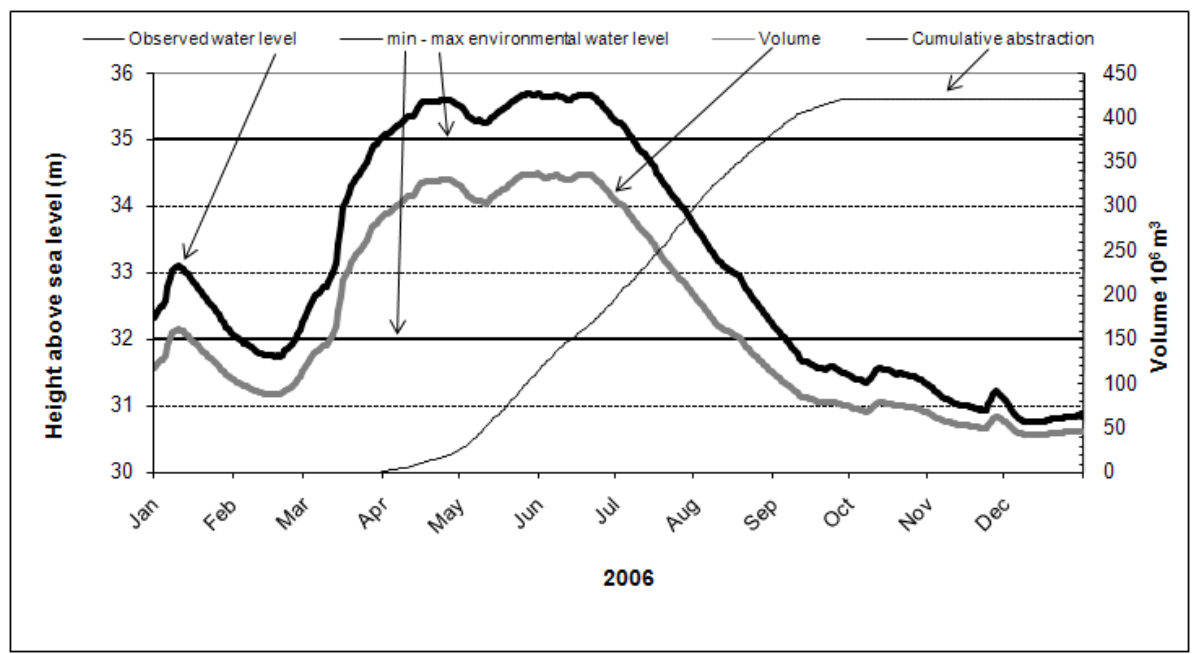

(c)

Figure $\mathbf{7}(\mathbf{a}, \mathbf{b}, \mathbf{c})$. Variation in water level and corresponding water volume in Lake Kerkini, and cumulative abstraction in irrigation networks fed by Strymonas River and Lake Kerkini for 2004-2006 
By June $9^{\text {th }}, 2004$, lake water reached its peak and $111 \times 10^{6} \mathrm{~m}^{3}$ had been distributed from the lake to irrigated land and an extra $235 \times 10^{6} \mathrm{~m}^{3}$ was necessary. Considering net lake volume on maximum ecological level, reaches $214 \times 10^{6} \mathrm{~m}^{3}$. Let's suppose that water balance of inflow - losses in the lake is null, when in practice it is always positive, then only $21 \times 10^{6} \mathrm{~m}^{3}$ is left. This shortage could be saved merely by improving transfer network efficiency by just $4 \%$.

On $13^{\text {th }}$ June 2005 , water shortage was about $91 \times 10^{6} \mathrm{~m}^{3}$, when ecological water level was maintained, which may be compensated by a $16 \%$ improvement in network efficiency.

On $21^{\text {st }}$ June 2006 water shortage reached $40 \times 10^{6} \mathrm{~m}^{3}$. Maintaining ecological level in the lake could be achieved by a $7 \%$ increase in network efficiency.

Overall, therefore, a $16 \%$ increase in irrigation network efficiency could meet on one hand the irrigation water demands and on the other hand a decrease of the maximum lake water level, necessary to protect marginal wetlands. Also it would increase river discharge downstream of the Lake Kerkini thereby reducing seawater intrusion into Strymonas River estuary.

The hopeful conclusion in cases like the one presented in this study is that simple solutions could have very positive results in areas where the water resources management is not developed.

\section{Acknowledgments}

Data was collected in the course of LIFE Strymon project. The Greek Biotope/Wetland Centre (EKBY) was the beneficiary of the project and I wish to thank all EKBY staff who contributes to the project implementation. Also we would like to thank Dr. S.E.R Bailey for his corrections and comments on the manuscript.

\section{References}

Andersen J., Refsgaard J. And Jensen K. (2001), Distributed hydrological modelling of the Senegal River Basin - model construction and validation, Journal of Hydrology, 247, 200-214.

Antonopoulos V. (1999), Hydrology of the unsaturated soil zone, Aristotle University of Thessaloniki, Thessaloniki. (in Greek)

Apostolakis A.N. (2007), Crop pattern identification in Strymonas basin using satellite image analysis. In Halkidis I and Papadimos D (Editors) (2007), Technical report of LIFE Environment project: Ecosystem Based Water Resources Management to Minimise Environmental Impacts from Agriculture Using State of the Art Modeling Tools in Strymonas Basin, Greek Biotope/Wetland Centre (EKBY), Thermi, Greece.

DHI, 2003a. MIKE SHE an integrated Hydrological Modelling System - User Guide. Danish Hydraulic Institute, Denmark.

DHI (2003b) MIKE 11 an integrated Hydrological Modelling System - User Guide. Danish Hydraulic Institute, Denmark.

Feyen L., Vazquez R., Christianes K., Sels O. and Feyen J. (2000), Application of a distributed physically-based hydrological model to a medium size catchment, Hydrology and Earth System Sciences, 4(1), 47-63.

Gerakis P.A., Tsiouris S., Tsiaoussi V. (Editors) (2007) Water regime and biota: proposed minimum values of lakes water level and of river discharge in Macedonia and Trace, Greece, The Goulandris Natural History Museum/Greek Biotope-Wetland Centre, Thermi, (in Greek, summary in English).

Halkidis I., Papadimos D. and Mertzianis Ch. (2004), Strymonas Basin Integrated Surface Water \& Groundwater Model, Phase I, Input Data and Model Set up, Greek Biotope/Wetland Centre (EKBY), Thermi, Greece.

Halkidis I., Papadimos D. (Editors) (2007a) Ecosystem Based Water Resources Management to Minimise Environmental Impacts from Agriculture Using State of the Art Modeling Tools in Strymonasas Basin, Technical report of LIFE Environment project. Greek Biotope/Wetland Centre (EKBY), Thermi, Greece.

Halkidis I., Papadimos D. (2007b) Technical Report. Strymonas basin integrated surface water and groundwater model - Phase II. Calibration, validation and sensitivity analysis of the model, Greek Biotope/Wetland Centre (EKBY), Thermi, Greece.

Nash J.E. and Sutcliffe J.V. (1970), Riverflow forecasting through conceptual models. Part 1: a discussion of principles, Journal of Hydrology, 10, 282-290. 
Refsgaard J.C. (1997), Parameterisation, calibration and validation of distributed hydrological models, Journal of Hydrology, 198, 69-97.

Sahoo G.B., Ray C. and De Carlo E.H. (2006), Calibration and validation of a physically distributed hydrological model, MIKE SHE, to predict stream flow at high frequency in a flashy mountainous Hawaii stream, Journal of Hydrology, 327, 94-109.

Singh R., Subramanian K. and Refsgaard J.C. (1999), Hydrological modelling of a small watershed using MIKE SHE for irrigation planning, Agricultural Water Management, 41, 149-166.

Thompson J.R., Refstrup Sørenson H., Gavin H. and Refsgaard A. (2004), Application of the coupled MIKE SHE/MIKE 11 modelling system to a lowland wet grassland in southeast England, Journal of Hydrology, 293, 151-179.

Van Genuchten M. (1980), A closed form equation for predicting the hydraulic conductivity in unsaturated soils, Soil Science Society Journal of America, 44, 892-898. 